\title{
Role of Organizational Flexibility in Enhancing Sustainable Green Management Practices: A Study in Emerging Market Context
}

\author{
Dr. Broto Rauth Bhardwaj, Head, Research and Entrepreneurship Dept., \\ Bharati Vidyapeeth University, Institute of Management and Research, New Delhi \\ brotorauth@yahoo.com \\ A.R. Deshmukh, Director, School of Distance Education, \\ Bharati Vidyapeeth University, Institute of Management and Research, New Delhi \\ amarsuja@yahoo.com
}

\begin{abstract}
Purpose - The purpose of this paper is to identify the variables influencing the role of organizational flexibility in enhancing sustainable organization (SO) by adopting green management practices. The empirical research study identifies the characteristics of internal environment to enhance sustainable green management practices in firms operating in an emerging economy, such as India.

Design/methodology/approach - The authors studied a sample size of 62 firms all over India and measured the internal environment for enhancing sustainable green management practices. In total, 142 responses were collected. Using SPSS tool, the authors measured the impact of these variables on sustainable outcomes.

Findings - It was found that the critical variables with respect to Indian context included management support, and organizational flexibility for developing environmentally sustainable organization.

Research limitations/implications - Further confirmatory research needs to be conducted to establish the stability of these factors. The results need to be tested on a larger sample size. Moreover, the tool developed needs to be tested for other emerging economy context too for generalization.

Practical implications - Organizational flexibility would enhance the sustainable capability of the companies to compete by enhancing their competitiveness in emerging economies by adopting green management practices. Therefore, it would be critical to study the role of green management practices in enhancing the sustainability and competitiveness of the firms operating in the Indian economy.

Originality/value - Earlier studies have not included two important parameters, including role of organizational flexibility and management support as drivers of sustainable development even in the developed country context. Moreover, the influence of organizational flexibility on green management practices needs to be studied in the context of sustainable development which was missing in the earlier literature.
\end{abstract}

\section{Indexing terms/Keywords}

sustainable organization, organizational flexibility, management support

\section{Academic Discipline And Sub-Disciplines}

Strategic management

Organisational flexibility

\section{SUBJECT CLASSIFICATION}

Business and Management

TYPE (METHOD/APPROACH)

Empirical study, research paper type

\section{Council for Innovative Research}

Peer Review Research Publishing System

Journal: International Journal of Management \& Information Technology

Vol.4, No.3

editor@cirworld.com

www.cirworld.com, member.cirworld.com 


\section{INTRODUCTION}

In the globalization era, which has brought about unprecedented changes in the service and manufacturing economy, organizations of all sizes and structures are searching for strategies to improve performance without sacrificing quality. With rapid change in firms' environment the organizations must renew the firm capability which harmonizes to the new competition and its ability can create competitive position (Teece et al., 1997). Thus, firm flexibility or strategy was providing capability to respond environmental change and create competitive advantage. Still other studies have explored the various processes and activities needed to develop and exploit dynamic capabilities for competitive advantage (Zahra, Sapienza and Per Davidsson, 2006). Teece et al. (1997) identify a dynamic capability as the firm's ability to address rapidly changing environments. While entrepreneurs and managers are the key agents of change, dynamic capabilities may also be embedded in organizational routines and may be employed to reconfigure the firm's resource base by shedding idle or decaying resources (Sirmon et al., 2006), or recombining resources in innovative ways that develop virtually new substantive capabilities in existing or new market arenas (Kogut, and Zander, 1992). Dynamic capabilities may be most valuable when the external environment is changing rapidly or unpredictably (Zahra et al., 2006). Strategic flexibility can offer a firm that has a distinctive competitive advantage, because the capabilities to generate decision-making options, and hence different forms of strategic flexibility to deal with dynamic and changing environments, is probably difficult for competitors to imitate. Successful adaptation through strategic flexibility will likely generate superior performance, exacerbating the imitation problem for competitors. Flexibility in adopting information technology can also enhance sustainability (Mangal, 2010).

The study contributes in the following two ways. Firstly, the present study enhances the role of organizational process, particularly, organizational flexibility dimension in enhancing the sustainability of the organization through adoption of green management practices. Secondly, the study identifies the role of management support in sustainable development of the organization. The aim of this study was to analyze the role of corporate entrepreneurship, staff cynicism, and strategic flexibility on firm's competitiveness. Our objective is to find the answer for the research question: how does strategic flexibility effect firm's competitiveness. Then, how does corporate entrepreneurship and staff cynicism affect strategic flexibility and firm's competitiveness.

The remaining part of this study is structured as follows. First, the relevant literature on all construct is reviewed. Second, the research method of the study is described. Third, the results of the empirical study are discussed. Finally, the study ends with theoretical and managerial contributions, suggestions for future research and conclusion.

\section{LITERATURE REVIEW}

This study attempts to understand the role of organizational flexibility in enhancing firm's competitiveness by adopting green management practices. The research model of this study, organizational flexibility, is an independent variable, which includes two components of complexity and centrality. Researcher explore the key antecedent include two factors of corporate entrepreneurship and staff cynicism. In addition, the study investigates change experience as the moderator of the effect of corporate entrepreneurship and staff cynicism on strategic flexibility.

\subsection{Organizational flexibility}

The flexibility is defined as the degree of freedom given for CE activities including planning, identification of suppliers and implementation of plan. Flexibility is also defined as the degree of freedom of action in terms of roles and responsibilities. Three aspects characterize systemic flexibility: options, change and freedom of choice. Identification of flexibility on any plane requires delineation of the range of options (Sushil, 2000, 2006). Barret and Weinstein (1998) defined flexibility as the degree to which a business unit is adaptable in administrative relations and the authority is vested in situational expertise (Zenger and Marshall, 2000; Stajkovic and Luthans, 2001; Hornsby and Kuratko, 2003). The dimension 'existence of a supportive organizational structure' (Sathe, 1985) provides the administrative mechanisms by which ideas are evaluated, chosen and implemented (Covin and Slevin, 1991; Palanisamy, 2001). Other researchers have also emphasized on the appropriate organizational structure, which provides organizational flexible boundary within the organization (Guth and Ginsberg, 1990). Slater and Narver (1995) proposed that a firm's market orientation is complemented by entrepreneurship and organizational flexibility.

The development of the requisite "strategic flexibility" (Eisenhartdt and Tabrizi, 1995) in the customer intelligence development process is critical aspect of CE. Practicing flexibility, particularly in performance appraisal and reward systems, encourage people for risk taking and innovation (Guth and Ginsberg, 1990). Flexibility in organization structure contributes positively towards products success (Saleh and Wang, 1993). Graham (1995) emphasized the need to match the organic structure to a proactive management style, which facilitates good communication and the free flow of information for effective market orientation (Stopford and Baden-Fuller, 1994).

Cameron (1986) has argued that extremity in any criterion of effectiveness creates linearity and dysfunction. Some balance must be present in opposition. Effective organizations demonstrate proactivity and entrepreneurship as well as stability and control. However, too much action and innovation may create loss of direction, wasted energy, and a disruption of continuity. An overemphasis on control and coordination can produce stagnation, loss of energy, and abolition of trust and morale. Miller (1990) showed how entrepreneurial momentum becomes dysfunctional when not 
opposed by countervailing force. He analyzes the forces that lead to excessive momentum, for example, leaders with big egos, overconfidence, and defense mechanisms. Similarly, Loenard-Barton (1995) proposed how success leads companies to overshoot the target. Miller added to this literature by describing how some companies recovered from excesses, and others avoided excesses and remained excellent. Stopford and Badenfuller (1994) stated that renewing organizations surmount challenges which had previously appeared impossible; often a creative process of resolving internal dilemmas. Shumpeterian entrepreneurship is about combing what had been regarded as mutual opposites and harnessing the outcome as innovation in the market (Poole and Van de Ven, 1989).

The literature has emphasized on the type of control-financial verses strategic, but more important question to be answered is the purpose of control. Drucker (1954) addressed this issue by emphasizing the purpose of control as to empower and educate managers to make their own decisions. Although tight financial controls associated with large diversified firms can lead to a short-term, low risk orientation (Hoskisson and Hitt, 1988), Barringer and Bluedorn (1999) found that strategic controls are positively associated with greater entrepreneurial intensity. Researchers have found that strategic and financial controls seem to be necessary for new business creation.

The use of "boundaryless" cross-functional new product development teams with good market input from both customers and non-customers helps to create robust product designs that do not need to be reworked in later stages of development after substantial resources have been expended in development and production. In general, shifting the relative allocation of time, effort, and resources toward the early phases of new product development reduces the overall cost and development time which translates to increased cumulative profit for the new product.

The key issues related to Organizational Flexible Boundary are given in Table 1.

Table 1: Key Issues in Organizational Flexible Boundary

\begin{tabular}{|c|c|}
\hline Author(s) & Key Issues \\
\hline Graham (1995) & $\begin{array}{l}\text { Good communication and free flow of information throughout the } \\
\text { organization characterize high flexibility. }\end{array}$ \\
\hline $\begin{array}{l}\text { Stopford and Baden-Fuller } \\
\text { (1990) }\end{array}$ & $\begin{array}{l}\text { Flexibility and internal communication is necessary for implementing } \\
\text { CE. }\end{array}$ \\
\hline Volberda (1998), Sushil (2006) & $\begin{array}{l}\text { A firm's revitalization requires flexible structure that facilitates } \\
\text { communication across the functional boundaries. This is also known as } \\
\text { entrepreneurial revitalization. }\end{array}$ \\
\hline Slater and Narver (1995) & $\begin{array}{l}\text { Organizational flexibility results into organizational learning in terms of } \\
\text { customer satisfaction, growth and profitability. }\end{array}$ \\
\hline Singh and Lewis (1997) & $\begin{array}{l}\text { High degree of flexibility in the product development activities is very } \\
\text { important for CE. }\end{array}$ \\
\hline Singh and Lewis (1997) & $\begin{array}{l}\text { Structured but flexible development process helps the firms to adapt to } \\
\text { the ever changing market environment. }\end{array}$ \\
\hline Millet (1990) & $\begin{array}{l}\text { Processes should have inbuilt flexibility to handle the likely problems } \\
\text { which may not have been planned at the beginning of the project. }\end{array}$ \\
\hline Thomke and Reinertsen (1998) & $\begin{array}{l}\text { Three ways to improve developmental flexibility include flexible } \\
\text { technologies and structured processes, which can lower the cost of } \\
\text { subsequent changes in initial product architecture. }\end{array}$ \\
\hline Saleh and Wang (1993) & $\begin{array}{l}\text { Flexibility in organization structure contributes positively towards CE } \\
\text { success. }\end{array}$ \\
\hline Haddad (1996) & $\begin{array}{l}\text { Human resource flexibility in terms of performance appraisal and } \\
\text { reward systems encourage people for innovation. }\end{array}$ \\
\hline $\begin{array}{l}\text { Stopford and Baden-Fuller } \\
\text { (1994) }\end{array}$ & $\begin{array}{l}\text { Flexible management structure facilitates communication across } \\
\text { boundaries. }\end{array}$ \\
\hline
\end{tabular}

Dougherty and Bowman (1995) argue that managers should support innovation sponsors and champions, retain oldtimers who are part of the key network, bolster the network by building more connections between departments, and between new and established businesses, and incorporate innovation directly into the firm's strategy.

Generally the firm favoring generative learning for creating products yields a competitive edge against firms using constrained linear thinking. Firms emphasize on structured but flexible development process so that appropriate 
corrections/deviations may be made depending upon the change in the market environment. Some firms develop links with customers to co-develop the product in the iterative process (lansiti and MacCormack et al., 2001).

This organization process was conforming the ability of firm to respond adapt to environmental change. Researchers hope its make contribution for strategic management field. Thus, this study required investigating role of organizational flexibility and management supporting enhancing sustainability of the organization.

Strategic flexibility is defined as the ability to precipitate intentional changes and adapt to environmental changes through continuous rethinking of current strategies, asset deployment and investment strategies. Any type of flexibility, whether strategic, tactical, or operational, will help the organization create greater value and sustainable competitive advantage (Javalgi, et al., 2005). SMEs may enjoy greater flexibility because of the simplicity of their internal organization, being faster at adopting to change (Aragon-Sanchez and Scanchez-Marin, 2005). Lingyee, and Ogunmokun (2007) indicated that range flexibility has a significant positive impact on new product innovation performance and cost-related economic performance.

Complexity (CP) defined as a result of the degree of differentiation (the range of internal and external environmental concepts included in the model) and integration (degree of connectedness among concepts) of the model. Complex strategy-related mental models embrace a wide range of strategic logics and a diverse set of alternative strategic solutions. At the organizational level, they allow firms to notice and response to more stimuli, thus increasing their adaptability (Lyles and Schwenk, 1992). Complex mental models contribute to strategic flexibility by reducing discounting (the phenomenon of focusing in specific (more familiar) events ignoring other more important) and cognitive inertia (the search for specific events and causes to strengthen the dominant logic of the model). They allow managers to scan the environment and to respond to stimuli coming from it more effectively by considering more options and (eventually) implementing a wider range of them. Strategically complex organizations consider multiple views in formulating strategy and produce superior customer-based performance (Neill, and Rose, 2006). These arguments lead to the following hypotheses:

Hypothesis 1: Organizational flexibility influences sustainable organization positively.

\subsection{Management Support}

Management support is an important antecedent for CE. The Management support dimension indicates the willingness of managers to facilitate and promote entrepreneurial activity (Sykes and Block, 1989). Sathe (1989) emphasized upon the importance of management support in terms of encouraging the employees to take up innovative ideas. Researchers have emphasized upon management support in terms of providing necessary resources is critical for CE (Kuratko et al., 2005). Management Support can take many forms, including championing innovative ideas, providing necessary resources or expertise, or institutionalizing the entrepreneurial activity within the firm's system and processes. Management support was measured in terms of well-defined environmental responsibilities, full-time employees devoted to environmental management, natural environment training programmes for managers and employees, adopts green human resource development practices, product planning and control focused on reducing waste and optimization materials exploitation, systems for measuring and assessing environmental performance, periodic elaboration of environmental reports, regular voluntary information about environmental management to customers and institutions, and environmental emergency plans. The key issues in Management Support are listed in Table 2.

Table 2: Key Issues in Management Support

\begin{tabular}{|l|l|}
\hline Authors & Issues \\
\hline Quinn (1985) & $\begin{array}{l}\text { Willingness of managers to facilitate and promote entrepreneurial } \\
\text { activity is critical for CE. }\end{array}$ \\
\hline Hisrich and Peters (1986) & $\begin{array}{l}\text { The degree of willingness of managers to facilitate } \\
\text { entrepreneurship within the organization is an indicator of CE } \\
\text { success. }\end{array}$ \\
\hline Sykes and Block (1989) & $\begin{array}{l}\text { Institutionalizing the entrepreneurial activity within the firm's system } \\
\text { and processes is critical for CE. }\end{array}$ \\
\hline Sathe (1989) & $\begin{array}{l}\text { Management support is critical in terms of encouraging the } \\
\text { employees to take up innovative ideas. }\end{array}$ \\
\hline Stevenson and Jarillo (1990) & $\begin{array}{l}\text { Management support in terms of providing necessary resources or } \\
\text { expertise is critical for CE. }\end{array}$ \\
\hline Kuratko et al. (2005) & $\begin{array}{l}\text { Management support in terms of providing necessary resources is } \\
\text { critical for CE. }\end{array}$ \\
\hline
\end{tabular}

These arguments lead to the following hypotheses:

Hypothesis 2: Management support influences sustainable organization positively. 


\section{RESEARCH METHODOLOGY}

The study is divided into three phases: (i) the pilot study to identify the organizational antecedents of SO, (ii) questionnaire study to establish relationships among organizational antecedents for SO verify and enrich the SO model. The framework shows the structural variables and internal environmental variables which help develop SO. The framework also shows the relationship between management support and organizational flexibility which are the two dimensions undertaken in the study.

It uses questionnaire survey method, in which the unit of analysis is the firm. The questionnaire was developed and pre-tested before mailing to the selected organizations. To understand the correlation among the different variables, correlation analysis has been used. Based on the conceptual model evolved in this chapter, the hypotheses have been tested statistically through stepwise multiple regression technique and the results have been synthesized to identify the organizational antecedents impacting CE outcomes.

\subsection{Analysis}

The hypotheses of association for macro variables are tested by regression analysis. Since all the relationships are established through correlation analysis, no variables are dropped while carrying out the regression analysis. The study shows that Management Support (MS) is a major predictor of SO as shown in Table 3. The other predictors are Organizational flexibility. These variables together explain 46.4 per cent of the variance in SO; the rest is dependent on other variables and spurious variables not included in the model. The corresponding ANOVA values for the regression model are shown in Table 4 indicating validation at 99 per cent confidence level. The coefficient summary as shown in Table 5 gives Beta values of Management Support (MS) in terms of appointing full-time employees devoted to environmental management as 0.463 , which are fairly representative of their impact on the SO. The other significant variables defining management support includes clear objectives and long term environmental plans which impacts SO. Thus, Management Support (MS) is emerging as a major influence variable for SO.

Table 3: Model Summary of influence on Management Support on Sustainable Organization

\begin{tabular}{|l|l|l|l|l|}
\hline Model & $\mathrm{R}$ & $\mathrm{R}$ Square & $\begin{array}{l}\text { Adjusted } \mathrm{R} \\
\text { Square }\end{array}$ & $\begin{array}{l}\text { Std. Error of } \\
\text { the Estimate }\end{array}$ \\
\hline 1 & $.681(\mathrm{a})$ & .464 & .406 & .867 \\
\hline
\end{tabular}

a Predictors: (Constant), full-time employees devoted to environmental management, Explicit definition of environmental policy, well-defined environmental responsibilities, clear objectives and long term environmental plans

Table 4: ANOVA Summary of influence on Management Support on Sustainable Organization

\begin{tabular}{|l|l|l|l|l|l|l|}
\hline Model & & $\begin{array}{l}\text { Sum of } \\
\text { Squares }\end{array}$ & $\mathrm{df}$ & Mean Square & $\mathrm{F}$ & Sig. \\
\hline 1 & Regression & 24.083 & 4 & 6.021 & 8.007 & $.000(\mathrm{a})$ \\
& Residual & 27.822 & 37 & .752 & & \\
& Total & 51.905 & 41 & & & \\
\hline
\end{tabular}

a Predictors: (Constant), full-time employees devoted to environmental management, Explicit definition of environmental policy, well-defined environmental responsibilities, clear objectives and long term environmental plans b Dependent Variable: periodic elaboration of environmental reports

Table 5: Coefficients Summary of influence on Management Support on Sustainable Organization

\begin{tabular}{|c|c|c|c|c|c|c|}
\hline \multirow[b]{2}{*}{ Model } & & \multicolumn{2}{|c|}{$\begin{array}{l}\text { Unstandardized } \\
\text { Coefficients }\end{array}$} & \multirow{2}{*}{$\begin{array}{l}\text { Standardized } \\
\text { Coefficients } \\
\text { Beta } \\
\end{array}$} & \multirow[b]{2}{*}{$t$} & \multirow[b]{2}{*}{ Sig. } \\
\hline & & $B$ & Std. Error & & & \\
\hline \multirow[t]{4}{*}{1} & (Constant) & 3.549 & .681 & & 5.210 & .000 \\
\hline & $\begin{array}{l}\text { Explicit definition of } \\
\text { environmental policy }\end{array}$ & -.083 & .187 & -.063 & -.443 & .660 \\
\hline & $\begin{array}{l}\text { clear objectives and long } \\
\text { term environmental plans }\end{array}$ & -.024 & .189 & -.024 & -.126 & .900 \\
\hline & $\begin{array}{l}\text { well-defined environmental } \\
\text { responsibilities }\end{array}$ & .173 & .173 & .165 & .999 & .324 \\
\hline
\end{tabular}




\begin{tabular}{|l|l|l|l|l|l|}
\hline $\begin{array}{l}\text { full-time } \\
\text { devoted to environmental } \\
\text { management } \\
\text { (Constant) }\end{array}$ & .463 & .091 & .686 & 5.076 & .000 \\
\hline $\begin{array}{l}\text { Explicit definition of } \\
\text { environmental policy }\end{array}$ & -.354 & .179 & -.325 & -1.980 & .055 \\
\hline $\begin{array}{l}\text { clear objectives and long } \\
\text { term environmental plans }\end{array}$ & .389 & .137 & .466 & 2.845 & .007 \\
\hline
\end{tabular}

a Dependent Variable: periodic elaboration of environmental reports

The degree of organizational flexibility exercised by top management in appointing full-time employees devoted to environmental management impacts SO significantly. The degree of organizational flexibility in providing natural environment training programmes for managers and employees also influences SO significantly. The respective person correlation value is .801 at 0.000 significance level. Also it is shown in table that there is significant correlation between management support in providing natural environment training programmes for managers and employees to full-time employees devoted to environmental management. Moreover, it is also shown that periodic elaboration of environmental reports has significant relationship between orientation of full-time employees devoted to environmental management for SO. The table also shows that there is a significant correlation between product planning and control focused on reducing waste and optimization materials exploitation and flexibility in adopting green human resource development practices by the top management.

\section{CONCLUSIONS}

The study shows that there is a significant relationship between management support and sustainable organization (SO). Moreover the study findings also show that there is significant relationship between the management and organizational flexibility in executing the SO parameters.

The researcher implications include the study of the various dimensions of organizational flexibility and management support which enhances SO. The future researchers may also study the relationship between the various sub constructs and the SO outcomes including the role of product planning and control focused on reducing waste and optimization materials exploitation, role of flexible systems for measuring and assessing environmental performance on SO. The other dimensions of study may include flexibility in acquisition of clean technology/equipment, flexibility in substitution of polluting an hazardous materials/parts may influence the SO outcomes. The other avenues of research may include the relationship of SO and competitiveness.

The managerial implications may include the managers to take special care in exercising organizational flexibility in terms of degree of organizational flexibility exercised by top management in appointing full-time employees devoted to environmental management. This may be exercised in terms of providing natural environment training programmes for managers and employees. Further, according to the study, one of the critical success factors of SO is management support. Moreover, according to the study, the periodic elaboration of environmental reports will enhance the SO outcomes and help the organization to be environmentally sustainable in the long run (Comfort and Hillier, 2008).

\section{REFERENCES}

1. Aragon-Sanchez, A. \& Sanchez-Marin, G. 2005, 'Strategic Orientation, Management Characteristics, and Performance: A Study of Spanish SMEs', Journal of Small Business Management, vol. 43, no. 3, pp. $287-308$.

2. Barret H. and Weinstein A. (1998) The Effect of Market Orientation and Corporate Entrepreneurship, Entrepreneurship Theory and Practice, Fall, 57-70.

3. Barringer, B. R. and Bluedorn, A. C. (1999). The Relationship between Corporate Entrepreneurship and Strategic Management, Strategic Management Journal, 20, 412-444.

4. Cameron, K. S. (1986). Effectiveness as Paradox: Consensus and Conflict in Conceptions of Organizational Effectiveness, Management Science, 32, 539-553.

5. Comfort, D. and Hillier, D. (2008) Moving towards sustainable food retailing? International Journal of Retail \& Distribution Management; 2008, Vol. 36 Issue 12, p995-1001.

6. Covin J.G. and Slevin D.P. (1991) A Conceptual Model of Entrepreneurship as Firm Behavior, Entrepreneurship Theory and Practice, 16(1), 7-25.

7. Dougherty, D. and Bowman, E. H. (1995) The Effects of Downsizing on Product Innovation, California Management Review, 37(4), 28-44. 
8. Drucker, P. F. (1954) The Practice of Management, New York: Harper and Row.

9. Eisenhartdt K.M. and Tabrizi B.N. (1995) Accelerating Adaptive Processes: Product Innovation in the Global Computer Sector, Academy Management Journal, 32(3), 543-576.

10. Graham P. (1995) Mary Parker Follet - Prophet of Management, Boston: Harvard Business School Press.

11. Guth W. D. and Ginsberg A. (1990) Guest Editors' Introduction: Corporate Entrepreneurship, Strategic Management Journal, 11, 5-15 (special issue).

12. Haddad C.J. (1996) Operationalising the Concept of Concurrent Engineering: A Case Study from the US Auto Sector, IEEE Transactions on Engineering Management, 43(2), May, 124-132.

13. Hisrich R. D. and Peters M.P. (1986) Establishing a New Business Venture Unit Within a Firm, J. Bus. Venturing, 1, 307-322.

14. Hornsby J.S. and Kuratko D.F. (2003) The Influence of Entrepreneurial Environment on Job Satisfaction, Reinforcement Practices and Behaviors. Paper presented at the United States Association for Small Business and Entrepreneurship, Hilton Head, SC.

15. Hoskisson, R. E. and Hitt, M. A. (1988). Strategic Control Systems and Relative R\&D Investment in Large Multiproduct Firms, Strategic Management Journal, 9, 605-621.

16. Iansiti M. and MacCormack A. (1997) Developing Products on Internet Time, Harvard Business Review, SepOct, 108-117.

17. Javalgi, R., V. Pioche Khare, A. Gross, and R. Scherer. 2005. An application of the consumer ethnocentrism model to French consumers. Int. Bus. Rev. 14:325-344.

18. Kogut, B., \& Zander, U. 1992. Knowledge of the firm, combinative capabilities, and the replication of technology.

19. Organization Science, 3: 383-397.

20. Kuratko D.F., Ireland R.D., Covin G. J. and Hornsby J.S. (2005) A Model of Middle Manager's Entrepreneurial Behavior, Entrepreneurship Theory and Practice, Nov, 699-716.

21. Ling-yee, and Ogunmokun, "An empirical study of manufacturing flexibility of exporting firms in China: How do strategic and organizational contexts matter?" Industrial Marketing Management, IMM-06161, 2007, p 1-14.

22. Loenard-Barton, D. (1995). Wellsprings of Knowledge: Building and Sustaining the Sources of Innovation, Boston: Harvard Business School Press.

23. Lyles, M. and Schwenk, C., "Top management, Strategy, and Organizational Knowledge Structures", Journal of Management Studies, 29, 1992, 155-174.

24. Miller, D. (1983). The Correlates of Entrepreneurship in Three Types of Firms. Management Science, 29, pp770-791.

25. Millet S.M. (1990) The Strategic Management of Technological R\&D: An Ideal Process for 1990s, International Journal of Technology Management, 5(2), 153-163.

26. Narver J. C. and Slater S.F. (1990) The Effect of a Market Orientation of Business Profitability, Journal of Marketing, October, 20-35.

27. Neill, S. and Rose, G. M., "The effect of strategic complexity on marketing strategy and organizational performance", Journal of Business Research, 59, 2006, 1-10.

28. Palanisamy R. (2001) Evolving Internet Business Model for Electronic Commerce using Flexible Systems Methodology, Global Journal of Flexible Systems Management, 2(3), 1-12.

29. Poole, M. S. and Van de Ven, A. H. (1989). Using Paradox to Build Management and Organization Theories, Academy of Management Review, 14, 562-678.

30. Quinn J.B. (1979) Technological Innovation, Entrepreneurship and Strategy, Sloan Management Review, (Spring), 19-30.

31. Saleh S.D. and Wang C.K. (1993) The Management of Innovation: Strategy, Structure and Organizational Climate, IEEE Transactions on Engineering Management, 40(1), 14-20.

32. Sathe V. (1985) Managing the Entrepreneurial Dilemma: Nurturing Entrepreneurship and Control in Large Organizations, Frontiers of Entrepreneurship Research, 636-656.

33. Singh K.J. and Lewis J.W. (1997) Concurrent Engineering: Institution, Infrastructure and Implementation, International Journal of Technology Management, 14(6/7/8), 727-738.

34. Slater S.F. and Narver J.C. (1995) Market Orientation and the Learning Organization, Journal of Marketing, 59(3), 63-74.

35. Stajkovic A.D. and Luthans F. (2001) Differential Effects of Incentive Motivators on Work Performance, Academy of Management Journal, 44, 580-591.

36. Stevenson H.H. and Jarillo J.C. (1990) A Paradigm of Entrepreneurship: Entrepreneurial Management. Strategic Management Journal, 11, 17-27.

37. Stopford J.M. and Baden-Fuller C.W. (1994) Creating Corporate Entrepreneurship, Strategic Manage. J., 15, 521-536.

38. Sushil (2000) Concept of Systemic Flexibility, Global Journal of Flexible Systems Management, 1(1), 77-80.

39. Sushil (2006) Leadership and Organizational Revitalization, in Explorations in Management Thought by Deepak Dogra and Vinay Auluck, 148-158, Ane Books India Publications.

40. Sykes H.B. and Block Z. (1989) Corporate Venturing Obstacles: Sources and Solutions, J. Bus. Venturing, 4, 159-167. 
41. Teece, D. J. (1987) Profiting from Technological Innovation: Implications for Integration, Collaboration, Licensing, and Public Policy, In D. J. Teece (ed.), The Competitive Challenge: Strategies for Industrial Innovation and Renewal, Cambridge, MA: Ballinger, 185-219.

42. Thomke S.H. and Reinertsen D. (1998) Agile Product Development: Managing Flexibility in Uncertain Environment, California Management Review, 41(1), Fall, 8-30.

43. Mangal, Vandana Ann (2010) Sustainability - is it for the ClO? Electronic Green Journal, 1(29), http://escholarship.org/uc/item/0rp658mr

44. Volberda H.H. (1998) Building the Flexible Firm: How to Remain Competitive, Oxford University Press.

45. Zahra, Shaker A., Harry J. Sapienza and Per Davidsson (2006) Entrepreneurship and

46. Dynamic Capabilities: a Review, Model and Research Agenda, Journal of

47. Management Studies, 43, 4, June, 917-955.

48. Zenger T.R. and Marshall C.R. (2000) Determinants of Incentive Intensity in Group-based Rewards, Academy of Management Journal, 43(2), 149-164.

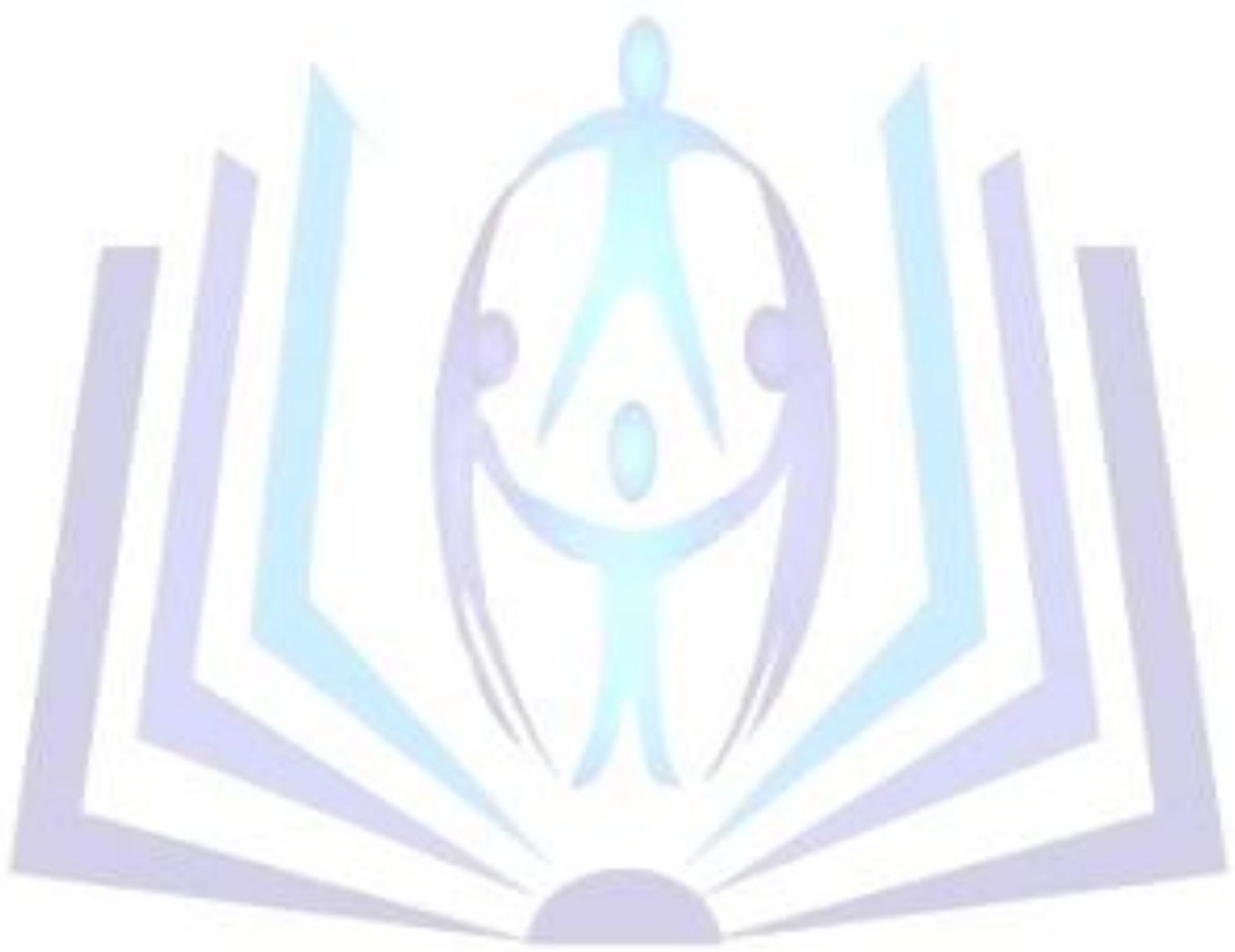

